\title{
CONTROVERSIAL ISSUE INSTRUCTION IN CONTEXT: A Social Studies Education Response to the Problem of the Public
}

\section{Thomas Misco}

\section{INTRODUCTION}

At the end of The Public and Its Problems (Dewey, 1927/1954), John Dewey alighted upon the "the problem of the public," which is the improvement of the "methods of debate, discussion, and persuasion" (p. 208). Given Dewey's conception of democracy, one which is squarely focused on communicated experiences (Dewey, 1916) and beginning in conversation (as cited in Lamont, 1959, p. 88), the problem of the public (as well as the resolution) is congruent with the problem of democracy (Dewey, 1927/1954). The vibrancy of democratic citizens in terms of their decision-making and efforts toward improving the common good is predicated on the ability to improve discussion and debate, which is based on "freeing and perfecting the process of inquiry" (Dewey, 1927/1954, p. 208). Reflective inquiry, as the method of intelligence in a democracy, is not naturally occurring, nor a facile process. Rather, reflective inquiry demands fortitude, patience, circumspection, open-mindedness, wholeheartedness, and responsibility (Dewey, 1933). These skills and requisite dispositions are taught and practiced, but to what end? Reflectively inquire about what? Many societies truncate that which can be reflected upon, leaving citizens to ponder ideas and topics in unwholesome corners, without the guidance of an intelligent teacher (Dewey, 1940).

The major barrier to reflective inquiry is habit, often found in tradition and custom. Habits, including prejudice or pre-judgment, bind us and routinize our affairs whereby false idols of knowledge (Dewey, 1933), those of impulse, tradition, authority, and personal experience, serve as vices to both reflection and communication. Dewey most saliently tackled these issues in How We Think (1933) and The Theory of the Moral Life (1908/1960) and alerted us to the tocsins of the public, but also democracy itself. In particular, the tense dualities of public and private, as well as customary and dynamic morality, thwart citizens' rational consideration of beliefs and construction of knowledge.

The intersection of these tense dualities is where controversial issues live. In this sense, controversial issues, which are avoided or ignored within non-reflective habits, are the underlying problem for the public, both domestically and abroad. 
To what extent can or will schools provide the conditions for teachers and students to broach controversial issues and invite them to the method of reflective inquiry? The ideal Dewey advanced to resolve the problem of the public was conversation, reflective inquiry, and improved "conjoint communicated experience," (1916, p. 87) or democracy, all of which are predicated on the milieu, which provides pathways or obstacles to these ends. Facts need "free play" (Dewey, 1927/1954, p. 3) and any fatuous value of a priori ends, especially in matters of ethics, which Dewey equated with "human relations in action" (Dewey, 1893, p. 57), highlights the importance of context. In short, the milieu very much matters for the extent to which the public's problem can be solved.

\section{The Importance of Controversial Issues for Democracy}

Controversial issues are integral to democratic education (Camicia, 2008; Engle, 1960; Engle \& Ochoa, 1988; Graseck, 2009; Hahn, 1991; Harwood \& Hahn, 1990; Hess, 2008; 2009; Hunt \& Metcalf, 1968; Lee, 2004; Ochoa-Becker, 2007; Oliver \& Shaver, 1966). Controversies constitute a normative anchor within citizenship education curriculum, and the degree to which they are subjected to reflection has profound implications for the vibrancy of a democracy. Engaging controversial issues pays a democratic dividend for student-citizens by increasing civic participation, critical thinking skills, interpersonal skills, content understanding, and political activity. These judgments also elevate interest in current events, social studies, social issues, and increase the development of tolerance while developing democratic values, such as open-mindedness, dissent, skepticism, and embracing diversity (Curtis \& Shaver, 1980; Goldensen, 1978; Harwood \& Hahn, 1990; Hess \& Ganzler, 2006; Hess \& Posselt, 2002; Hess, 2009; Misco, 2010a, 2011a; Remy, 1972; Torney-Purta et al., 2002).

Schooling is supposed to challenge local traditions (Hlebowitsh, 2005), and unearthing controversies can help shift student focus from authoritative narratives and perspectives to heterogeneous micronarratives that draw on and challenge local and individual knowledge (Levinson, 2008). Addressing controversial issues can help widen and enlarge student experiences in terms of the normativity of topics, but also in the multiple perspectives entertained among teachers and peers to establish understandings and formulate solutions without succumbing to the tyranny of forced meaning (Giroux, 1983) and the often seductive appeal of prevailing belief and opinion. The process of discussing controversial issues can overlap with ideological battles outside the school, or within it, but it trumps those in light of the essential mandate for students to deliberate about the common good, take a stand on issues, and look at problems with multiple sources and perspectives (Hess, 2004; Marcus \& Stoddard, 2009).

There are no nomothetic prescriptions for teaching controversial issues independent of context and certainly no "easy answers" for devising their enactment within learning experiences (Barton \& McCully, 2007, p. 127). Sometimes a critical 
obstacle hinges on the "social and political winds" that blow through the school and "grab hold of the curriculum in a way that limits the range of expression that can emerge" (Hlebowitsh, 2005, p. 222). Yet, decontextualized fidelity approaches to curriculum implementation have enjoyed a resurgence within a measurement and high-stakes era of teaching, whereby context, or milieus, can overpower other commonplaces to stymie the discussion of controversial issues (Misco, 2010b). When teachers subscribe to a fidelity model, controversies are often no longer considered important or are rendered independent of social context and milieus, which also puts enactment at risk. In addition, pushing too far into a zone of discomfort can often invite rejection of enactment (McCully, 2006; Patrick, 2005). Given these hazards, the sociohistorical location of the teacher and the negotiation of context is critical for the normative decision about what should be done about an issue, which is typically underpinned by the differences in "key beliefs or understandings about the issue held by the protagonists" (Oulton, Dillon, \& Grace, 2004, p. 411).

\section{The Contextual Milieus}

Schwab (1973) distilled educational phenomena into four commonplaces, where someone is teaching something to someone, somewhere (teacher, subject matter, learner, and milieu), all of which demand coordination when we focus on the ultimate goal of doing what is best for the learner as a human being, child, and citizen. It is the final commonplace, which Schwab referred to as "the milieus," that includes the school, classroom, and relations of students to each other. The relations of students to subgroups, students to structures of authority, teachers to educational leaders, as well as student to student, teacher to student, and teacher to teacher all help shape not only what is taught, but how it is taught. Other relevant milieus include the "family, community, the particular groupings of religious, class or ethnic genus" (p. 367) and the aspirations of these groups. Milieus are also located in the relations of groups and individuals within town, city, country, and locale as "represented in miniature" by the students of each genus (p. 367). Many of these milieus, in the form of school structure, community members, and parents who want students to reflect their views, undermine a marketplace of ideas and act as barriers to discussion of controversy (Hess, 2009).

Schwab (1973) suggested that connected to these milieus are what teachers will know, the degree of flexibility they bring to teaching and learning new techniques, as well as the "biases they bring" (p. 367). When considering controversial issues within overlapping milieus, Schwab emphasized whether learning experiences will not only lead to the improvement of the community, but also if they will be acceptable to the community and, if not, what steps can be taken to facilitate acceptance. Teacher preparation, student relations, and the juxtaposition of multiple layers of incommensurable values suggest that these milieus are of paramount concern for designing learning experiences that address controversial issues. Even 
with a provocative curriculum, eager students, and well-prepared teachers poised to confront controversy, the milieus act as pathways and obstacles to opening and discussing closed areas. Controversial issues span both societal and educational knowledge domains, and learning about these issues entails a negotiation between the individual and their social milieu (Barnett \& Hodson, 2001; Misco, 2012).

\section{Reflective Thinking And Improving the Process of InQuiry}

The use of reflective thinking (Dewey, 1933; 1908/1960) can help disrupt historical silences, address controversial issues, and assist students in moving beyond settled societal attitudes and beliefs. Reflective inquiry is the method of intelligence in a democracy, and its consistent and pervasive employment can bring about a great number of the skills and dispositions needed for democratic citizenship, as well as the development of higher-order thinking skills (Misco \& Shiveley, 2010). Dewey (1933) defined reflective thinking as the "active, persistent, and careful consideration of any belief or supposed form of knowledge in light of the grounds that support it and the further conclusions to which it tends" (p. 9). It is a process that seeks to resolve a problem and reach a resolution, whereby any data, inference, or belief that does not aid in the resolution of the problem is jettisoned in favor of that which does. The end goal controls the ideas and it is rooted in a state of doubt-a "felt difficulty," perplexity, or some "cerebral itch" that demands resolution (p. 6).

If there is no question or felt difficulty, students will act according to habit. Dewey referred to such habits as assumptions that develop unconsciously and become a "part of our mental furniture" (p. 7). These inherited and settled beliefs become legitimized as sources of knowledge not subjected to active thinking. Beliefs of this kind, including assumptions about historical events, race, class, gender, sexual preference, immigration, divergent religious beliefs, and corruption, need to be revisited within the context of schooling. They must be evaluated and turned over so as to problematize the source of belief with knowledge and the experience of humanity. With the influx of new information and perspectives, beliefs can give rise to questions that are inimical to dualistic assumptions and students can reconstruct these beliefs on the basis of evidence and reason. In order to think reflectively, one must protract and sustain a state of doubt and enter a search for evidence and relevant factual features grounded in tentative conclusions, understandings, and resolutions on legitimate footing. The ultimate justification and evaluation of evidence, which constitutes the higherorder thinking required of democratic citizens, must rest on a substantive ensemble of evidence. Otherwise, faulty and incomplete evidence undermines the rigorous goals of reflection. Alternatively, many students want to move quickly and hasten the hunting and weighing of evidence. But, as Dewey (1933) warned, we can only think reflectively when we are "willing to endure suspense and to undergo the trouble of searching" (p. 16). This, then, is the charge of the teacher-to supply the appropriate tools, resources, and inducements, as well as ensure a proper protraction of doubt. 
Without reflection, the beliefs generated within school may not be any better than those brought into the classroom - they may also be prejudices (Hunt \& Metcalf, 1968). The "right" or "correct" answers sought for high-stakes exams, highly specific standards, and easily quantified summative assessments are not the stuff of reflection and are injurious to the undermining of undemocratic beliefs. Given the essential nature of protracted doubt within the reflective process, and the forces working on teachers that ultimately reduce instructional time and authority, the resultant tension is the fulcrum between harmonious, tolerant, and active citizenry and a passive version that accepts and perpetuates prejudices (Misco, 2011a).

Engaging in reflective inquiry about a wide variety of controversial issues often results in students negotiating normative or moral terrain. Problems are connected to solutions, both of which may reside within contested spaces. Engaging these issues inevitably produces discomfort, frustration, and escalated emotions, as multiple realities collide within topics and issues that are not frequently open for conversation. But in order for a classroom to truly be reflective, any problem, value, idea, and topic must be opened for free examination (Engle \& Ochoa, 1988). Transition to true democratic life requires an achievement that takes generations to advance: that of releasing and encouraging "occasions for doubt" (Griffin, 1942, p. 84) rather than minimizing or suppressing them. The idea of a correct belief held over from authoritarian and totalitarian cultures is as dangerous as the absence of rational beliefs or reticence on the topic.

\section{A Case of Milieu Influencing InQUiRy INTO CONTROversial Issues: CHINA}

During his visit to China (1919-1921), Dewey provided a sagacious and somewhat prophetic roadmap for Chinese moral educators. Chief among his recommendations was the need to integrate the method of reflective thinking with the development of morals and values, while avoiding any attempt to impart moral knowledge through traditional or direct methods (Wang, 2007). Warning against the path the west chose, which led to increased individualism and a contracted moral ken, Dewey focused on the need to cultivate a dynamic morality, through reflection, whereby new valuations of the good and the right evolve as a result of changing conditions and experiences, as well as a revaluation of existing values. Dewey's grounding in dynamic environments and experiences influenced reflective morality to the extent that students could accommodate moral belief structures and progress towards a consciousness where the "existence of a persistent self and the part it plays in what is externally done" is realized (Dewey, 1908/1960, p. 15).

Dewey noted that cultivating this moral character was "the goal of education" (Wang, 2007, p. 21) and that the school day is "pregnant with moral possibility" (Dewey, 1909, p. 58). The process of reflective morality was to act not only as a 
fulcrum for moral and citizenship education, but also as the fountainhead of the school day and the democratic realization of self and society (Hoyt, 2006). Dewey viewed reflective morality as addressing the struggle of incompatible belief systems that exist between the domains of individual, family, religion, school, and community, milieus which often seem incongruous.

At the time, Dewey recognized a recurring focus on the products, rather than the processes, of educational activity in China (Wang, 2007). Although not a hemispheric distinction, the deontological and teleological schism within moral education is quite salient for understanding differing approaches to citizenship education and what Dewey referred to as the "morality of custom," which includes the values and principles implying universal acceptance. Usually formalistic and legalistic, morality of custom does not require thought or consideration of future circumstances (Dewey, 1908/1960). Often manifest in the form of school rules and routines, which typically end in students viewing morality as arbitrary (Dewey, 1909), complexity and nuance of reality could be glossed over in favor of "mindless obedience to some codified moral authority or rule book" (Lockwood, 2009, p. 101). Instead, Dewey advised China to eschew blind adherence to the authority of tradition, which existed as a false idol of knowledge (Dewey, 1933) and replace it with the authority of scientific inquiry. In particular, he had hoped China would consider this form of moral education, even though it was not pervasive in the West, when considering new educational reforms (Wang, 2007).

During his final talk in China (1921), titled "the Importance of Dynamic Morality," Dewey suggested that,

The static and passive morality which was characteristic of China may produce strong and enduring character, but it stresses obedience and filial piety; dynamic morality, on the other hand, stresses creativity, venturesomeness and willingness to assume responsibility ... in a democratic state where maintenance of social equilibrium and progress of social reconstruction are functions of individual responsibility, dynamic morality must be cultivated. (as cited in Wang, 2007, p. 25-26)

Dewey's assertion that China should cultivate dynamic morality was quite prescient. The occasions for doubt and exploration of controversy, as substance for reflective thinking on moral issues, are nascent features of China's iterative moral education curriculum. Dewey's finding that China relied heavily on the products and not processes of educational experience is no longer the case. The aforementioned schism is undergoing a yearly dialectic, with the gradual expansion of scientific thinking expanding and a priori, ideological presuppositions receding.

Chinese moral education now squarely fits within a human-centered paradigm (Zhu \& Feng, 2008). The current and official charge of moral education is to uphold the socialist aims of the school and society whereby the Communist Party of China (CPC) explicitly dictates that "moral education is ideological and political 
education" (Lee \& Ho, 2005, p. 414). Although all subjects are required to address morality in some form, moral education largely takes place in formal classes and as an extra-classroom experience (Misco, 2011b).

The most recent moral education curricular iteration has liberated students from this and placed an "emphasis on being practical and realistic and prepared for new challenges" (Wansheng \& Wujie, 2004, p. 531). In spite of the political side of moral education seeming indoctrinaire to Western readers at a prima facie level (Ping et al., 2004), the educational goals have broadly moved from moral inculcation to modernization, competition, and the revitalization of China through education, with an increased focus on the individual (Zhao, 2004). Still, within this reconceptualization is a philosophical distinction between West and East, whereby in China more stress is placed on obligations and responsibilities, in contrast to a Western focus on balancing rights and obligations (Zhu \& Feng, 2008).

Although the revised moral education embodies an increased focus on the individual and is more reflective, one obstacle for reflective morality has been a lack of focus on contemporary topics, which may be a lasting effect from previous iterations marking a struggle for change (Chen \& Reid, 2002). A challenge of reconceptualizing moral education in many post-communist countries is that the education teachers and parents received is quite different from new iterations (BukBerge, 2006). If China is "no longer a closed society" (Wanxue \& Hanwei, 2004, p. 469), perhaps it is now ready to provide a more reflective morality and help students confront controversial issues. China is enjoying a time of "moral deregulation" and decentralization, which presents a unique opportunity for the larger trend of China's movement on the "democratization track" (Lee \& Ho, 2005, p. 425-427). Yet, lingering questions center upon how future iterations will respond to the intellectual and socioeconomic developments and the extent to which it can keep pace with political and social changes while maintaining stability. If it becomes more reflective and democratic, citizens could very well begin to explore heretofore closed areas.

Moral education classes tend to err on the side of the personal, rather than tackling the difficult public, contemporary, and historic issues. The avoidance of this rich terrain puts these classrooms at risk of rendering moral education irrelevant if it focuses on the uncomplicated and banal. Many closed areas and controversial issues are not open to reflection, including national unity. Teachers perceive issues that are controversial in other cultures and contexts, such as drugs, sex, and sexuality, as distant from students' lives. In some cases, these teachers recognized other topics as controversial, including unemployment or filial piety, and obviated the genuine controversies as closed (Misco, 2011b; 2013).

Chinese students encounter numerous challenges to reflective thinking about controversial issues. Due to the pervasive nature of dualistic thinking, which is related to the debate cultures found elsewhere in Asia, but which is very much a vice of reflective thinking (Dewey, 1922), students could easily find safe quarter 
within the Manichean distinctions of their moral education classrooms. Students encounter curriculum that focuses more heavily on high-stakes exam preparation and content suggestive of prescriptive guidance and deference to collective wisdom rather than individual inquiry into contested issues. Teachers rely heavily on methods of direct instruction and would at times engage in inculcation and assume a position of holding the "right" answers to normative and moral questions. Parents typically are supportive of the teacher as a purveyor of moral knowledge and schools ultimately filter and render controversies within the curriculum, which draws student attention away from the "negative things." By focusing primarily on controversies that are either historical or local in nature, students often feel a lack of meaningfulness and relevance to course topics and instead engaged in issues lacking substantive social significance (Misco, 2013).

In contrast with communist states that transitioned to democracy abruptly, China exhibits a move to the individual as the unit of analysis and the permeation of a student-centered and constructivist pedagogy that values diversity of student ideas on moral issues, and critical, independent, and reflective teaching strategies are coming to be commonplace. This move, situated within a larger context of the market economy and Chinese governmental goals of participation and leadership in a globalized world (Lee \& Ho, 2008), has similarities to the National Council of the Social Studies' (2010) statement on powerful teaching and learning for democratic citizenship, including learning experiences that are active, meaningful, value-based, challenging, and integrative. The shift to students' real lives with relevant, engaging, and exciting classes is an indicator of nascent democratic social education.

The current employment of reflective thinking in this fashion, whereby students learn "how to deal with political and moral issues, rather than giving preset answers to all problems" (Ping et al., 2004, p. 459), presents a shift towards a deontological approach to moral education. Although respondents suggested that reflective capacities exist, the revaluations of some ideas and institutions are closed off from circumspection. Students in these classes may very well have moral felt difficulties but these may not necessarily be broached in the school.

China has embarked upon gradual reconceptualization of moral education and is well-positioned to institute more comprehensive democratic education reforms in the future. Changes to moral education curriculum and pedagogy may serve to alleviate the frustrations of closed areas among citizens and ultimately offer an avenue for increasingly open and frank deliberations concerning the ethicality of social, political, and economic issues through a more critical lens. In short, moral education in China has the potential to be a non-violent lever for transition to more effective citizenship education through reflective inquiry, perhaps better positioned than mature democracies that have taken an expurgated approach to moral education and controversial issues (Misco, 2011b, 2013). 


\section{Freeing And Perfecting the Process of InQUiRy}

I began this article with Dewey's syllogism concerning the problem of the public. In short, the charge of social educators is to improve the "methods of debate, discussion, and persuasion" (1927/1954, p. 208), which is predicated upon "freeing and perfecting the process of inquiry" (Dewey, 1927/1954, p. 208). In the case of China, Confucian culture permeates the milieus whereby teachers, parents, and the Ministry of Education curriculum directives closely adhere to a morality of custom (Dewey, 1908/1960) on matters of controversy. Moral education within a communist and authoritarian context stymies discussions about controversial issues within China, though increased attention to reflective thinking in this educational context is becoming more prominent. Similar to other countries, teachers in China appear to lack a strong rationale of, or urgency for, discussing controversial issues using the method of reflective inquiry (Misco, 2011b).

The problem of the public Dewey alighted upon, the need to perfect the process of inquiry, is a challenge for any society. The obstacles and barriers thwarting the resolution of this problem are tradition, custom, habit, impulse, and authority, all of which serve to undermine reflection and discussion (Dewey, 1933). As both democratic and authoritarian societies strive to provide more rights and freedoms for their citizens and become more democratic in terms of conjoint communicated experience, they will need to address citizenship education in the form of discussion and reflection about controversial issues. This is thus the problem of not only all publics, but all governments, ministries of education, and institutions that claim, or aspire to advance, democratic education.

\section{REFERENCES}

Barnett, J., \& Hodson, D. (2001). Pedagogical content knowledge: Toward a fuller understanding of what good science teachers know. Science Teacher Education, 85(4), 426-453.

Barton, K., \& McCully, A. (2007). Teaching controversial issues . . where controversial issues really matter. Teaching History, 127, 13-19.

Buk-Berge, E. (2006). Missed opportunities: The IEA's study of civic education and civic education in post-communist countries. Comparative Education, 42(4), 533-548.

Camicia, S. P. (2008). Deciding what is a controversial issue: A case study of social studies curriculum controversy. Theory and Research in Social Education, 36(4), 298-316.

Chen, Y., \& Reid, I. (2002). Citizenship education in Chinese schools: retrospect and prospect. Research in Education, 67, 58-69.

Curtis, C. K., \& Shaver, J. P. (1980). Slow learners as the study of contemporary problems. Social Education, 44(4), 302-309. 
Dewey, J. (1893). Teaching ethics in the high school. In J. A. Boydston (Ed.), John Dewey: The Early Works, Vol. 4, 1882-1898. Carbondale: Southern Illinois University Press.

_-_. (1908/1960). The theory of the moral life. New York: Holt, Rinehart, \& Winston.

_-_. (1909). Moral principles in education. Cambridge: Riverside.

_-_. (1916). Democracy and education. New York, NY: The Free Press.

_-_. (1922). Human nature and conduct. In J. A. Boydston (Ed.), The middle works of John Dewey, 1899-1924, V. 14. Carbondale: Southern Illinois University Press.

_-_- (1927/1954). The public and its problems. New York, NY: H. Holt.

- - - (1933). How we think. Lexington, MA: D.C. Heath \& Company.

-_- (1940). Censorship not wanted. In J. A. Boydston (Ed.), John Dewey: The later works, 1925-1953 (p. 373). Carbondale, IL: Southern Illinois University Press.

Engle, S. H. (1960). Decision making. In. W. C. Parker (Ed.), Educating the democratic mind (pp. 117-125). Albany: State University of New York Press. (Original work published 1960).

Engle, S. H., \& Ochoa, A. S. (1988). Education for democratic citizenship: Decision making in the social studies. New York: Teachers College Press.

Giroux, H. A. (1983). Theory and resistance in education: A pedagogy for the opposition. South Hadley, MA: Bergin \& Garvey.

Griffin, A. F. (1942/1996). Teaching in authoritarian and democratic states, in Parker, W. C. (Ed.) (1996). Educating the democratic mind (pp. 79-94). Albany: State University of New York Press.

Goldenson, D. R. (1978). An alternative view about the role of the secondary school in political socialization: A field experimental study of the development of civil liberties attitudes. Theory and Research in Social Education, 6(1), 44-72.

Graseck, S. (2009). Teaching with controversy: Educators awaken student voice by providing a safe place for dialogue about immigration, war, and other hot-button issues. Educational Leadership, 67, 45-49.

Hahn, C. L. (1991). Controversial issues in social studies. In J. P. Shaver (Ed), Handbook of research of social studies teaching and learning (pp. 470-482). New York, NY: Macmillan.

Harwood, A. M., \& Hahn, C. L. (1990). Controversial issues in the classroom. Bloomington, IN: Eric Clearinghouse for Social Studies Education (ERIC Document Reproduction Service No. ED327453).

Hess, D., \& Ganzler, L. (2006). Patriotism and ideological diversity in the classroom. In J. Westheimer (Ed.), Pledging allegiance: The politics of patriotism in America's schools (p. 131-138). New York: Teachers College Press.

Hess, D., \& Posselt, J. (2002). How high school students experience and learn from the discussion of controversial public issues. Journal of Curriculum and Supervision, 17(4), 283-314. 
Hess, D. (2004). Discussion in social studies: Is it worth the trouble? Social Education, $68(2), 151-156$.

- - - (2008). Controversial issues and democratic discourse. In L. S. Levstik \& C. A. Tyson (Eds.), Handbook of research in social studies education (pp. 124-136). New York, NY: Routledge.

-_- (2009). Controversy in the classroom: The democratic power of discussion. New York, NY: Routledge.

Hlebowitsh, P. S. (2005). Designing the school curriculum. Boston, MA: Allyn \& Bacon.

Hoyt, M. W. (2006). John Dewey's legacy to China and the problems in Chinese society. Transnational Curriculum Inquiry, 3(1). 12-25.

Hunt, M. P., \& Metcalf, L. E. (1968). Teaching high school social studies. New York, NY: Harper and Row.

Lamont, C. (Ed.). (1959). Dialogue on John Dewey. New York, NY: Horizon Press

Lee, W. O. (2004). Perception of citizenship qualities among Asian educational leaders. In D. Grossman, K. Kennedy, \& G. Fairbrother (Eds.), Citizenship education in Asia and the Pacific: Concepts and issues (pp. 137-156). Hong Kong: Kluwer Academic Publishers.

Lee, W. O., \& Ho, C. H. (2005). Ideopolitical shifts and changes in moral education policy in China. Journal of Moral Education, 34(4), 413-431.

Lee, W. O., \& Ho, C. H. (2008). Citizenship education in China: Changing concepts, approaches and policies in the changing political, economic and social contest. In J. Arthur, I. Davies, \& C. Hahn (Eds.), The SAGE handbook of education for citizenship and democracy (pp. 139-157). London, England: Sage.

Levinson, R. (2008). Promoting the role of the personal narrative in reaching controversial socio-scientific issues. Science and Education, 17(8-9), 855-871.

Lockwood, A. L. (2009). The case for character education. New York: Teachers College Press.

Marcus, A. S., \& Stoddard, J. D. (2009). The inconvenient truth about teaching history with documentary film: Strategies for presenting multiple perspectives and teaching controversial issues. The Social Studies, 100(6), 279-284.

McCully, A. (2006). Practitioner perceptions of their role in facilitating the handling of controversial issues in contested societies: a northern Irish experience. Educational Review, 58(1), 51-65.

Misco, T. (2010a). Responding to the thin veneers of controversial issues: The promises and challenges of curriculum implementation in post-communist schools. International Journal for Education, Law, and Policy, 6(1), 77-87.

- - - (2010b). Moving beyond fidelity expectations: Rethinking curriculum reform for controversial topics in post-communist settings. Theory and Research in Social Education, 38(2), 182-216. 
- - . (2011a). "Most learn almost nothing": Building democratic citizenship by engaging controversial history through inquiry in post-communist Europe. Education, Citizenship, and Social Justice, 6(1), 87-104.

- - - (2011b). Deontological reconceptualization: A study of moral education in Beijing. Theory and Research in Social Education, 39(4), 298-316.

- - - (2012). The importance of context for teaching controversial issues in international settings. International Education, 42(1), 69-84.

- - . (2013). "We do not talk about these things": The problems and challenges of reflective thinking and controversial issue discussions in a Chinese high school. Intercultural Education, 24(5), 401-416.

Misco, T. \& Shiveley, J. (2010). "Seeing the forest through the trees: Some renewed thinking on dispositions specific to social studies education." The Social Studies, 101(3), 121-126.

National Council for the Social Studies. (2010). Expectations for excellence: Curriculum standards for the social studies. Washington, D.C.: NCSS.

Ochoa-Becker, A. (2007). Democratic education for social studies: An issues-centered decision making curriculum. Greenwich, CT: Information Age.

Oliver, D., \& Shaver, J. P. (1966). Teaching public issues in the high school. Boston, MA: Houghton-Mifflin.

Oulton, C., Dillon, J., \& Grace, M. (2004). Controversial issues teachers attitudes and practice in the context of citizenship education. Oxford Review of Education, 30(4), 489-507.

Patrick, J. (2005, August). Remembrance, reflection, reconciliation, and reformation: Imperatives of teaching and learning about the Holocaust within civic education for liberty and democracy. Paper presented at From the Past to the Future: Learning about the Holocaust within the Framework of Civic Education, Riga, Latvia.

Ping, L., Minghua, Z., Bin, L., \& Hongjuan, Z. (2004). Deyu as moral education in modern China: Ideological functions and transformations. Journal of Moral Education, 33(4), 449-464.

Remy, R. C. (1972). High school seniors' attitudes toward their civics and government instruction. Social Education, 36(9), 590-597.

Schwab, J. J. (1973). The practical: Translation into curriculum. In I. Westbury \& N. J. Wilkof (Eds.), Science, curriculum, and liberal education. Chicago: University of Chicago Press.

Torney-Purta, J., Lehman, R., Oswald, H., \& Schulz, W. (2002). Citizenship and education in twenty-eight countries. Amsterdam: International Association for the Evaluation of Education Achievement. Retrieved from http://www .wam.umd.edu/ jtpurta/interreport.htm

Wang, J. (2007). John Dewey in China. Albany, NY: SUNY Press.

Wansheng, Z., \& Wujie, N. (2004). The moral education curriculum for junior high schools in 21st century China. Journal of Moral Education, 33(4), 511-532. 
Wanxue, Q., \& Hanwei, T. (2004). The social and cultural background of contemporary moral education in China. Journal of Moral Education, 33(4), 465-480.

Zhao, Y. (2004). Curriculum change and development in Chinese social science education since 1980. International Journal of Social Education, 19(1), 27-33.

Zhu, X., \& Feng, X. (2008). On the development of citizenship education outlook in China. Frontiers of Education in China, 3(1), 1-21.

Thomas Misco, $\mathrm{PhD}$, is an associate professor of social studies education at Miami University.Email: miscotj@miamioh.edu. 